\title{
FAKTOR-FAKTOR YANG MELATARBELAKANGI ORANG TUA MELAKUKAN VERBAL ABUSE PADA ANAK USIA SEKOLAH 6-12 TAHUN DI KABUPATEN GARUT
}

Factors Underlying Parents Do Verbal Abuse in 6-12 Years Old School Children in Garut Regency

\author{
Zahara Farhan, Dede Suharta, Devi Ratnasari \\ STIKes Karsa Husada Garut. \\ E-mail: zaharafarhan1804@yahoo.com
}

\begin{abstract}
Abstrak
Verbal Abuse adalah segala bentuk ucapan oleh orang tua yang menyakitkan terhadap anak seperti mengancam, menakut-nakuti, serta melontarkan kata-kata kasar. Terdapat lima faktor yang menyebabkan orang tua melakukan verbal abuse terhadap anak. Pertama, faktor pengetahuan orang tua tidak mengetahui bahwa verbal abuse lebih bahaya daripada phsycal abuse, kedua, faktor pengalaman orang tua memiliki pengalaman yang sama sehingga cenderung untuk meniru, ketiga, dukungan keluarga terhadap anak dengan kelainan fisik maupun anak lahir yang tidak diharapkan. Keempat, faktor ekonomi karena kemiskinan ataupun pengangguran, dan kelima, faktor lingkungan orang tua menjadi kaku dalam hal mendidik anak. Desain penelitian crossectional dengan jumlah sample 50 orang tua (ayah atau ibu). Teknik pengambilan sampel purposive sampling dan analisa yang digunakan menggunakan regresi logistik. Faktor pengalaman merupakan faktor yang paling dominan dalam melatarbelakangi orang tua melakukan verbal abuse pada anak usia sekolah 6-12 tahun di Desa Cintakarya Samarang Kabupaten Garut. Orang tua yang waktu kecilnya mendapat perlakuan kasar merupakan situasi pencetus terjadinya kekerasan pada anak. Pengalaman orang tua yang dulu dibesarkan dalam kekerasan cenderung meneruskan pendidikan tersebut kepada anak-anaknya. Anak yang mendapat perlakuan kejam dari orang tuanya akan menjadi sangat agresif dan setelah menjadi orang tua akan berlaku kejam kepada anak-anaknya.
\end{abstract}

Kata Kunci: verbal abuse, Anak Usia Sekolah, Orang Tua

\begin{abstract}
Verbal abuse is any form of negative statement from parents toward children such as threatening, fightening, or saying hurtful words. There are five factors that cause parents abuse their children verbally. First, knowledge factor, parents are poorly equipped with the knowledge about how verbal abuse can be more harmful than physical abuse. Second, experience factor, parents who experienced verbal abuse in their past tend to treat their children the same way. Third, family support, children with special need and unwated children are also considered as one of the factors. Fourth, economic factors such as poverty or unemployment. Fifth, environmen factor, the parents now to better for their children. The research sample 50 parent (mother or father) have children age 6-12 years. Sampling technic using purposive sampling. Analysis using regresion logistic. Experience factor was the most dominant factor for the parents doing verbal abuse to children 6-12 years at cintakarya-samarang-garut. Parents whose childhood treatment is mistaken is a trigger situation for child abuse. The experience of parents who were raised in violence tended to continue the education to their children. Children who get cruel treatment from their parents will be very aggressive and after becoming parents they will be cruel to their children
\end{abstract}

Keyword: Verbal abuse, parents, children, school age 


\section{PENDAHULUAN}

Anak usia sekolah saat ini akan lebih banyak mengalami stres dibandingkan dengan generasi sebelumnya, lingkungan sekolah salah satunya yang menyebabkan anak stress karena label yang diberikan terhadap anak oleh guru misalnya kamu bodoh atau tidak mampu. Dan adanya persaingan prestasi antar teman sebanya nya (Wong, dkk 2008).

UNICEF (United for Children) pada tahun 2016 mendefinisikan bahwa tindakan kekerasan terhadap anak adalah segala bentuk tindakan baik berupa fisik maupun psikologis, dimana kejadian tersebut biasanya dilakukan di lingkungan rumah, sekolah, masyarakat, suatu lembaga, tempat pengasuhan maupun tempat kerja. Kekerasan dapat melukai psikis anak dan akan berdampak jangka panjang. Terry E. Lawson, psikiater anak membagi kekerasan terhadap anak menjadi 4 (empat) macam, yaitu emotional abuse, verbal abuse, physical abuse dan sexual abuse. Verbal abuse akan terjadi ketika anak melakukan kesalahan dan ibu akan memberikan perlakuan kasar dalam bentuk verbal. Semua tindakan verbal abuse terhadap anak-anak direkam di alam bawah sadar mereka dan dibawa sampai kepada masa dewasa.

Berdasarkan data UNICEF (United for Children) pada tahun 2016 bahwa 80\% anak usia 2-14 tahun pernah mengalami kekerasan baik itu berbentuk fisik maupun psikologis dimana $62 \%$ kekerasan terhadap anak terjadi di lingkungan terdekat yaitu keluarga dan lingkungan sekolah, selebihnya $38 \%$ di ruang publik (Fitriani, Putra, Santoso, 2015).
Terdapat berbagai faktor yang menyebabkan orang tua melakukan verbal abuse terhadap anaknya. Pertama, faktor pengetahuan, yaitu orang tua tidak mengetahui pertumbuhan maupun perkembangan anaknya, orang tua tidak mengetahui bahwa verbal abuse ini sangat berbahaya lebih bahaya daripada phsycal abuse. Kedua, faktor pengalaman, yaitu orang tua tidak mengetahui bahwa segala sikap terhadap mendidik anak dilihat dari orang tua ayah ataupun ibunya, anak yang mendapatkan verbal abuse akan meniru tindakan orang tuanya ketika anak dewasa, anak akan tumbuh menjadi seseorang yang agresif. Ketiga, faktor keluarga, yaitu orang tua yang selalu menyalahkan terusmenerus kepada anaknya misalkan karena anak mengalami kelainan fisik misalkan cacat bawaan ataupun retradasi mental serta lahirnya anak tidak diharapkan. Keempat, faktor lingkungan, faktor ini adalah faktor yang datang dari luar yang bisa mempengaruhi dalam hal mendidik anak, orang tua menjadi kaku dalam hal mendidik anak karena orang tua menganggap mengetahui apa yang terbaik bagi anaknya. Kelima, faktor ekonomi, faktor ini berkaitan dengan kondisi status ekonomi keluarga seperti; kemiskinan, pendapatan, dan pengangguran. Adanya masalah dalam status ekonomi keluarga, orang tua terkadang melampiaskan kepada anak, anak yang dianggap sebagai milik orang tua terkadang menjadi korban dari ketidakpastian ekonomi (Kuspartianingsih, 2012).

Beberapa hasil penelitian yang dilakukan diantaranya penelitian yang dilakukan oleh 
Putri, Santoso (2012) mengungkapkan bahwa verbal abuse adalah kata-kata yang tidak pantas untuk diucapkan terhadap anak, orang tua berpendapat bahwa dampak yang akan terjadi dari verbal abuse ini tidak akan terlalu berat jika dibandingkan dengan kekerasan fisik. Penelitian yang dilakukan oleh Utami, Indriansari, dan Herliawati (2014) tentang Hubungan Kematangan Emosi Ibu Dengan Kekerasan Fisik dan Kekerasan Verbal pada Anak Usia Sekolah di SD Negeri 11 Indralaya didapatkan hasil bahwa perbandingan seorang ibu dengan keadaan emosinya yang tidak matang akan melakukan kekerasan secara verbal terhadap anaknya dengan presentasi $35 \%$ sedangkan ibu dengan emosi yang matang melakukan kekerasan verbal terhadap anaknya dengan presentai $47 \%$.

Hasil kajian empirik yang dilakukan di Desa Cinta Karya dan Desa Sirnasari Kabupaten Garut jumlah anak usia sekolah di Desa Sirnasari sebanyak 322 anak, dan di Desa Cintakarya sebanyak 532 anak. Penulis melakukan wawancara kepada orangtua yang mempunyai anak usia sekolah yaitu 6-12 tahun didapatkan bahwa, sebagian besar orang tua pernah melakukan verbal abuse atau kekerasan secara verbal kepada anaknya seperti membentak, berbicara kasar, mengancam dan ada yang sampai mengeluarkan kata-kata kasar ketika anak membuat kesal orang tuanya. Hasil kajian empirik juga didapatkan bahwa sebagian besar orang tua tidak mengetahui dampak yang akan terjadi kepada anaknya jika orang tua melakukan bentakan, ataupun ancaman terhadap anaknya.
Berdasarkan hasil beberapa kajian diatas, peneliti merasa tertarik untuk meneliti tentang Faktor - faktor yang Melatarbelakangi Orang Tua Melakukan Verbal Abuse pada Anak Usia Sekolah 6-12 tahun di Kabupaten Garut.

\section{TUJUAN PENELITIAN}

Untuk mengetahui faktor paling dominan yang melatarbelakangi terjadinya verbal abuse orang tua pada anak usia sekolah 6-12 tahun di Kabupaten Garut.

\section{METODE PENELITIAN}

Desain penelitian dengan cross sectional dengan variabel terikatnya verbal abuse, sedangkan variabel bebasnya faktor pengetahuan, pengalaman, dukungan keluarga, ekonomi, dan lingkungan. Data penelitian bersumber dari responden langsung melalui pengisian kuesioner. Sampel penelitian adalah orang tua (ayah atau ibu) dari keluarga yang memiliki anak usia sekolah 6-12 tahun. Teknik pengambilan sampel dengan rule of thumb sebanyak 50 orang dengan kriteria sampel sebagai berikut :

1. Ayah atau Ibu yang tinggal di daerah Desa Cintakarya dan Desa Sirnasari.

2. Ayah atau Ibu yang memiliki anak usia sekolah yaitu anak dengan usia 6 sampai 12 tahun.

3. Ayah atau Ibu yang bersedia menjadi responden.

4. Ayah atau Ibu tanpa kelainan anggota gerak. Penelitian dilakukan di Desa Cinta Karya dan Desa Sirnasari pada bulan Mei - Juli 2017. Data terlebih dahulu dilakukan uji normalitas 
dan didapatkan tidak berdistribusi normal sehingga analisis data yang digunakan dengan regresi logistik. Data diolah menggunakan software SPSS versi 20.

\section{HASIL PENELITIAN}

\section{a. Analisis Univariat}

Tabel 1. Hasil Uji Univariat Setiap Variabel

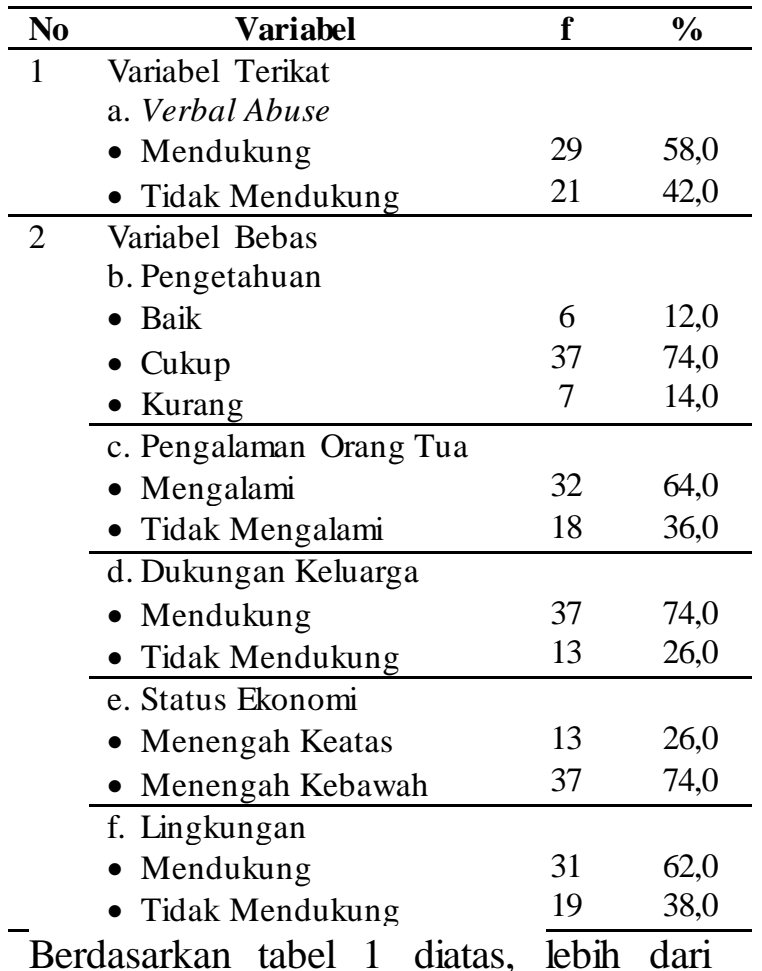

setengah orang tua (58\%) mendukung terjadinya verbal abuse kepada anaknya dengan dilatarbelakangi lebih dari setengah orang tua $(74 \%)$ memiliki pengetahuan yang cukup tentang pengetahuan verbal abuse, hampir setengah orang tua (36\%) pernah mengalami verbal abuse, hampir seluruh orang tua $(94 \%)$ tidak mendukung terjadinya verbal abuse, lebih dari setengah orang tua $(74 \%)$ memiliki status ekonomi menengah ke bawah, dan lebih dari setengah orang tua $(62 \%)$ berada pada lingkungan yang tidak mendukung terjadinya verbal abuse kepada anak di Kabupaten Garut.

\section{b. Analisis Bivariat}

Tabel 2. Hasil Uji Bivariat Masing-Masing Faktor dengan Verbal Abuse

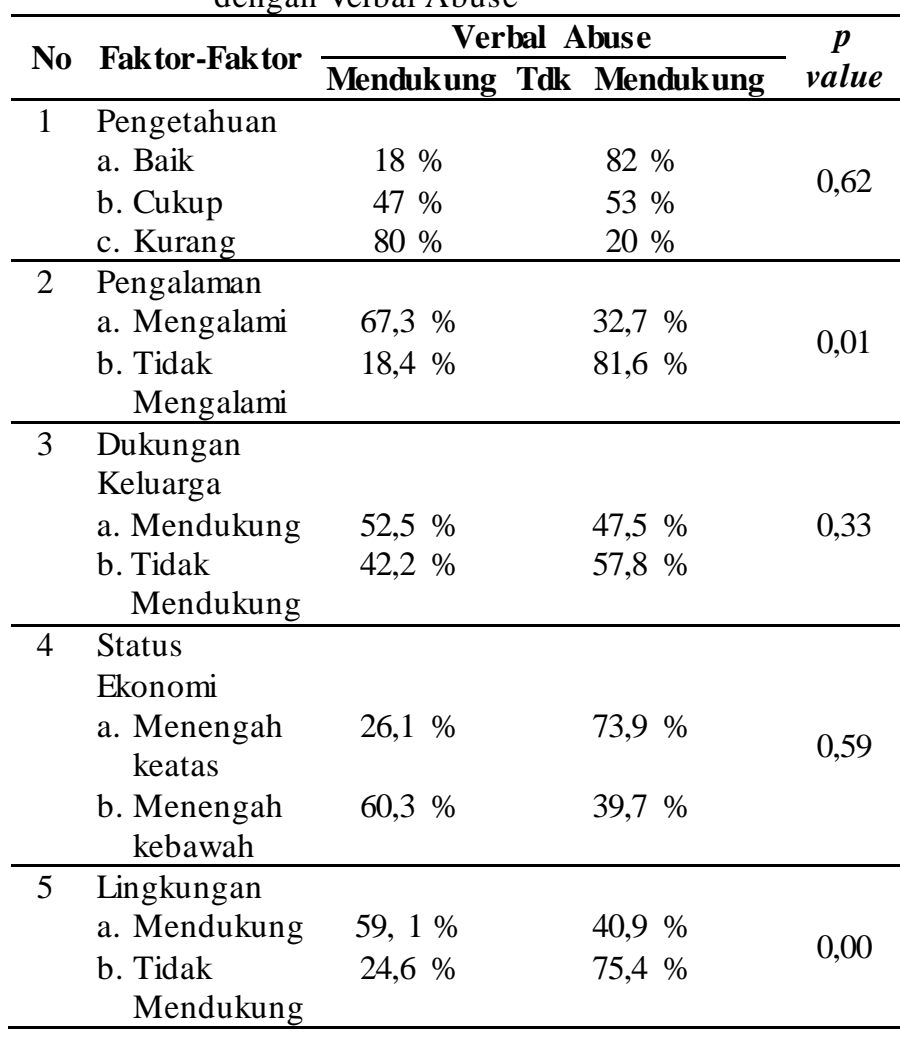

Berdasarkan tabel 2 diatas, faktor lingkungan dan faktor pengalaman merupakan faktor yang memiliki hubungan yang bermakna untuk terjadinya verbal abuse pada anak usia 612 tahun sekolah di Kabupaten Garut dengan masing - masing nilai p 0,01 dan 0,00 .

\section{c. Analisis Multivariat}

Tabel 3. Hasil Analisis Multivariat Keseluruhan Faktor dengan Verbal Abuse

\begin{tabular}{lccccccc}
\hline \multicolumn{1}{c}{$\begin{array}{c}\text { Faktor- } \\
\text { Faktor }\end{array}$} & B & S.E & Wald & df & Sig & $\exp (\mathbf{B})$ & $\begin{array}{c}\text { Nagel R } \\
\text { Square }\end{array}$ \\
\hline Pengetahuan & 1,53 & 1,33 & 1,32 & 1 & 0,25 & 4,60 & \\
Pengalaman & 2,12 & 0,79 & 7,27 & 1 & 0,01 & 8,34 & \\
Dukungan & $-2,97$ & 1,94 & 2,34 & 1 & 0,13 & 0,05 & \\
keluarga & & & & & & & \\
Ekonomi & 0,56 &, 83 & 6,30 & 1 & 0,51 & 1,74 & 0,30 \\
Lingkungan & $-1,61$ & 0,80 & 4,98 & 1 & 0,04 & 0,20 & \\
\hline
\end{tabular}

Berdasarkan tabel 3 diatas, faktor pengalaman merupakan faktor paling dominan 
yang melatarbelakangi terjadinya verbal abuse pada anak usia sekolah 6-12 tahun di Kabupaten Garut, hal ini dapat dilihat dari nilai wald sebesar 6,30. Dari hasil uji multivariat juga diketahui faktor pengalaman memiliki kemungkinan (peluang) 8 kali lebih besar untuk terjadinya verbal abuse pada anak usia sekolah 6-12 tahun di Kabupaten Garut, hal ini dapat dilihat dari nilai exponen $B$ sebesar 8,34 dibanding faktor yang lainnya. Selain itu, model ini mampu memprediksi sebesar $30 \%$ untuk terjadinya verbal abuse pada anak usia sekolah 6-12 tahun sebesar 30\%, hal ini dapat dilihat dari nilai Nagelkerke R - Square sebesar 0,30 .

\section{PEMBAHASAN}

a. Faktor - Faktor yang Melatarbelakangi terjadinya Verbal Abuse

Dari hasil penelitian di dapatkan bahwa orang tua yang mempunyai pengetahuan baik tentang verbal abuse (12\%), sedangkan yang mempunyai pengetahuan cukup (74\%), dan yang mempunyai pengetahuan kurang (14\%).

Faktor - faktor yang dapat mempengaruhi pengetahuan seseorang adalah pendidikan. Pengetahuan seseorang dapat bertambah bukan hanya dari pendidikan formal tetapi juga dari sumber informasi lain seperti; media masa ataupun media cetak. Orang tua yang tidak mengetahui atau hanya mengenal sedikit informasi mengenai perkembangan anak, dan mempunyai harapan-harapan yang tidak realistik anak, kurangnya pengetahuan orang tua tentang pendidikan anak dan minimnya pengetahuan agama orang tua juga turut berperan dalam melatarbelakangi kekerasan pada anak (Arimurti, Ida, 2005).

Berdasarkan hasil penelitian juga diketahui bahwa orang tua yang pernah mengalami verbal abuse sebesar $64 \%$, sedangkan orang tua yang tidak mengalami verbal abuse sebesar 36\%. Menurut Sekar (2014) pelaku kekerasan mempunyai masa lalu yang sarat dengan kekerasan. Akibatnya, terjadi proses peniruan dari peristiwa yang dilihat dan dialaminya, atau ada rasa ingin balas dendam dari apa yang dialaminya dengan mengulangi peristiwa tersebut. Perilaku kekerasan juga dipengaruhi oleh kepribadian seseorang: paranoid, narsistik, dan pasif - agresif memiliki kecenderungan untuk memiliki perilaku kekerasan. Anak yang mengalami atau menyaksikan peristiwa kekerasan dalam keluarga dapat menderita post traumatic stress disorder (stres pasca trauma). Selain itu, anak juga akan mengalami frustrasi yang dapat membuatnya berusaha mencari pelarian yang negatif seperti melalui alkohol atau penggunaan napza.

Berdasarkan hasil penelitian juga diketahui bahwa orang tua dengan dukungan keluarga yang mendukung terjadinya verbal abuse sebesar $74 \%$, sedangkan orang tua dengan dukungan keluarga yang tidak mendukung terjadinya verbal abuse sebesar 26\%. Menurut Solihin Lianny (2006), keluarga merupakan tempat pertama dan utama bagi anak untuk mendapatkan pembinaan mental dan pembentukan kepribadian, kemudian 
disempurnakan di sekolah maupun lingkungan tempat anak tumbuh dan berkembang. Fungsi dan peran keluarga memiliki andil yang sangat signifikan dalam perkembangan dan masa depan anak. Namun Sering dijumpai anak yang seharusnya mendapatkan perlindungan di dalam keluarga justru mendapatkan ketidaknyamanan dengan mendapatkan perilaku kekerasan. Anak yang seharusnya mendapatkan kasih sayang, perhatian, dan bimbingan dari orang tua dan anggota keluarga, tetapi justru mengalami hal yang sebaliknya, tempat yang seharusnya menjadi tempat teraman bagi anak, namun menjadi tempat terjadinya kekerasan. Akibatnya anak mengalami salah pengasuhan sehingga pada akhirnya pertumbuhan dan perkembangannya mengalami berbagai hambatan.

Karakteristik dukungan keluarga yang melatar belakangi terjadinya verbal abuse ini bisa saja disebabkan adanya jumlah anggota keluarga yang banyak, dan usia orang tua saat menikah yang masih dini (remaja) yang belum siap secara mental, emosional maupun finansial sehingga menyebabkan orang tua menjadi stres dan melampiaskan kemarahannya kepada anak.

Berdasarkan hasil penelitian diketahui, orang tua (ayah/ibu) dengan penghasilan > UMR kota Garut 1.500.000 (26\%), orang tua (ayah/ibu) dengan penghasilan < dari UMR kota Garut 1.500.000 (74\%).

Masalah keuangan seringkali mendorong timbulnya stress pada orangtua. Aspek keuangan dapat berupa tingkat penghasilan keluarga yang rendah serta dihadapkan dengan kebutuhan hidup yang sangat tinggi. Status ekonomi sangat berpengaruh pada perkembangan hubungan orang tua dengan anak. Pendapatan yang rendah seorang orangtua akan mengalami peningkatan perilaku yang negatif dimana orangtua akan mudah marah, tertekan dan frustasi yang akan berujung pada kekerasan verbal pada anak. Ekonomi merupakan salah satu faktor yang dapat menyebabkan verbal abuse pada anak, anak yang dianggap sebagai milik orang tua, orang tua berhak untuk bersikap apapun terhadap anaknya. Ketika orang tua yang tidak mempunyai pekerjaan, orang tua akan melampiaskan kepada anak, salah satu cara untuk melampiaskan dengan melakukan kekerasan secara verbal terhadap anak (Fitriani, Putra, Santoso, 2015).

$$
\text { Berdasarkan hasil penelitian }
$$
diketahui, orang tua dengan lingkungan yang mendukung terjadinya verbal abuse sebesar $62 \%$, sedangkan lingkungan yang tidak mendukung terjadinya verbal abuse sebesar 38\%. Munculnya masalah lingkungan yang mendadak seperti tekanan krisis ekonomi turut berperan untuk timbulnnya kekerasan verbal. Lingkungan sekitar tempat tinggal juga mempengaruhi pembentukan karakter anak, kebiasaan sering mendengar tetangga berkata kotor mengakibatkan hal yang sama. Selain dari lingkungan sekitar, berkembangnya media informasi turut menambah kemungkinan terjadinya kekerasan anak. Televisi sebagai suatu media yang paling efektif dalam menyampaikan berbagai pesan-pesan pada masyarakat luas berpotensial tinggi untuk 
mempengaruhi perilaku kekerasan yang dilakukan orang tua. Televisi merupakan media yang paling dominan pengaruhnya dibanding majalah maupun surat kabar (Rakhmat, J, 2006).

b. Hubungan Masing - Masing Faktor dengan Verbal Abuse

Berdasarkan hasil penelitian, faktor lingkungan dan faktor pengalaman merupakan faktor yang memiliki hubungan yang bermakna untuk terjadinya verbal abuse pada anak usia 612 tahun sekolah di Kabupaten Garut dengan masing - masing nilai p 0,01 dan 0,00. Pengalaman orangtua berpengaruh besar terhadap perilaku orang tua dalam melakukan kekerasan verbal terhadap anak. Orang tua yang mempunyai pengalaman baik mempunyai perilaku yang cenderung tidak melakukan kekerasan verbal pada anaknya, tetapi sebaliknya orang tua yang mempunyai pengalaman buruk cenderung melakukan kekerasan verbal terhadap anaknya (Fitriani, Putra, Santoso, 2015).

Menurut UNICEF (2016), kekerasan secara emosional atau secara psikologis akan terjadi jika gagal dalam menyediakan lingkungan yang mendukung anak dalam mengembangkan kompetensi sosial. Lingkungan sekolah, lembaga pengasuhan memainkan peranan penting dalam melindungi anak, namun bagi sebagian, lingkungan ini juga membuat anak terpapar berbagai resiko yang dapat terjadi seperti; hukuman fisik, bullying, atau perilaku kekerasan. c. Uji Multivariat Keseluruhan Faktor yang Melatarbelakangi Terjadinya Verbal Abuse

Berdasarkan hasil penelitian, faktor pengalaman merupakan faktor paling dominan yang melatarbelakangi terjadinya verbal abuse pada anak usia sekolah 6-12 tahun di Kabupaten Garut. Menurut Setiorini dan Indrawati (2016), pengalaman traumatik sebagai korban child abuse, masa kanak-kanak dengan pengalaman yang buruk memiliki pengaruh yang bersifat negatif pada masa dewasa awal, dan pengalaman child abuse mendorong keinginan untuk tidak melakukan kekerasan, memaafkan diri sendiri, memaklumi perilaku kekerasan orang tua, dan revitalisasi keluarga. Pengalaman mendapatkan kekerasan baik secara fisik maupun emosional, cenderung akan menyebabkan anak menunjukan sikap dan perilaku tertutup (introvert),kesulitan berhubungan dengan orang tua serta menjadi individu yang kurang asertif.

Orang tua yang waktu kecilnya mendapat perlakuan salah merupakan situasi pencetus terjadinya kekerasan pada anak. Pengalaman orang tua yang dulu dibesarkan dalam kekerasan cenderung meneruskan pendidikan tersebut kepada anak-anaknya. Anak yang mendapat perlakuan kejam dari orang tuanya akan menjadi sangat agresif dan setelah menjadi orang tua akan berlaku kejam kepada anak-anaknya (Kuspartianingsih, 2012).

\section{KESIMPULAN}

Pengalaman merupakan faktor paling dominan yang melatarbelakangi terjadinya verbal abuse dan memiliki kemungkinan 
(peluang) 8 kali lebih besar untuk menyebabkan terjadinya pada anak usia sekolah 6-12 tahun di Kabupaten Garut.

\section{DAFTAR RUJUKAN}

Arimurti Ida. Tujuh kalimat tabu yang diucapkan ayah dan ibu (online). http $/ /$ www.polarhome.com. 2005. Diakses Maret 2017.

Dahlan, M.S. (2013). Statistik Untuk Kedokteran dan Kesehatan. Jakarta : Salemba Medika. . (2013). Besar Sampel dan Cara Pengambilan Sampel. Jakarta : Salemba Medika.

Fitriana, Pratiwi, Sutanto. 2015. Faktor-Faktor Yang Berhubungan Dengan Perilaku Orangtua Dalam Melakukan Kekerasan Verbal Terhadap Anak Usia Pra Sekolah. Jurnal Psikologi Undip. Vol 14 No 1 April 2015, 81-93 .

Kuspartianingsih. 2012. Hubungan Antara Verbal Abuse Orang Tua Dengan Perilaku Agresif Remaja Agresif di Sekolah Menengah Pertama Negeri 129 Jakarta. Skripsi. Jakarta: PSIK FKIK UIN Syarif Hidayatullah.

Putri,Santoso. 2012. Persepsi Orang Tua Tentang Kekerasan Verbal Terhadap Anak. Jurnal Nursing Studies Vol 1 Nomor 1 halaman 22-29.

Rakhmat Jalaludin. Tindakan kekerasan terhadap anak. http://www.muthahari.or.id/doc/artikel/abu se.htm (online).2006 Diakses April 2017.

Sekar. 2014. Hubungan Antara Kekerasan Verbal Dengan Kepercayaan Diri Pada Remaja. Skripsi. Yogyakarta: Universitas Santha Dharma

Setiorini, Desiyanti dan Indrawati. 2016. Pengalaman Hidup Korban Child Abuse Dari Keluarga Broken Home (Studi Kualitatif fenomenologis Pada Dewasa Awal). Skripsi. Semarang: Fakultas Psikologi Universitas Diponegoro.

Solihin, Lianny. Kekerasan pada anak. http://www.bpkpenabur.or.id (online). 2005. Diakses Maret 2017.

Utami, Idriansari, Herliawati. 2014. Hubungan Antara Kematangan Emosi Ibu Dengan Kekerasan Verbal Pada Anak Usia Sekolah di SD Negeri Indralaya. Jurnal
MKS (online). Volume. 46 No. 1. Diakses Januari 2017.

UNICEF.org 2016. Angka Kejadian Kekerasan Terhadap Anak di Dunia Diakses Februari 2017.

Wong, Whaley. Clinical manual of pediatrics nursing. 4 th edition. Mosby: Year book. Inc. 1996 